\title{
Substituted benzyl $N$-phenylcarbamates - their solvolysis and inhibition activity to acetylcholinesterase and butyrylcholinesterase
}

\author{
Miloš Sedlák, ${ }^{a}$ * Jiří Hanusek, ${ }^{a}$ Pavel Drabina, ${ }^{a}$ Šárka Štěpánková, ${ }^{b}$ and Alexander Čegan ${ }^{b}$ \\ anstitute of Organic Chemistry and Technology, Faculty of Chemical Technology, University of \\ Pardubice, Nám. Čs. legii 565, 53210 Pardubice, Czech Republic \\ ${ }^{\mathrm{b}}$ Department of Biological and Biochemical Sciences, Štrossova 239, 53003 Pardubice, \\ Czech Republic \\ E-mail: milos.sedlak@upce.cz
}

\begin{abstract}
Kinetic evidence has indicated that methanolysis of synthesized 4-acetoxybenzyl carbamates proceeds via a one-step (concerted) mechanism. Concerted 1,6-elimination produces the very reactive 1,4-quinonemethide, which was trapped in the form of 4-methoxymethylphenol. The inhibition activity of benzyl $N$-phenylcarbamates to acetylcholinesterase (ACHE) and butyrylcholinesterase (BCHE) was also tested. The found $\mathrm{IC}_{50}$ values varied within the limits of 199-535 $\mu \mathrm{mol} \cdot \mathrm{l}^{-1}$ for ACHE and 21-177 $\mu \mathrm{mol} \cdot \mathrm{l}^{-1}$ for BCHE. The found values of partition coefficient $\left(\mathrm{P}_{\text {ow }}\right)$ in the range of 1.5-11.5 represent a prerequisite of good transport of benzyl $\mathrm{N}$ phenylcarbamates through haemato-encephalic barrier.
\end{abstract}

Keywords: Carbamates, 1,6-elimination, acetylcholinesterase, butyrylcholinesterase

\section{Introduction}

Carbamates $^{1}$ are a class of organic compounds possessing a number of suitable properties which can be utilized in industry, agriculture or medicine. For instance, in textile industry they have found applications as auxiliary textile agents. ${ }^{2}$ Eradication of dicotyledonous weeds ${ }^{3}$ is achieved by means of the carbamates Desmedipham and Fenmedipham. However, in recent years the greatest attention has been focused on research into new medical drugs. ${ }^{\text {a,b }}$ Priority is given to treatment of Alzheimer's disease, ${ }^{4}$ which affects a continuously increasing part of human population all over the world. An example of carbamate drug ${ }^{5}$ used for treatment of Alzheimer's disease is Rivastigmin ((S)- $N$-ethyl-3-[(1-dimethylamino)ethyl] $N$-methylphenylcarbamate, Exelon $^{\circledR}$ ) (Fig. 1) having the effect of cholinesterase inhibitors (CHEIs). 
<smiles>CCN(C)C(=O)Oc1cccc([C@@H](C)N(C)C)c1</smiles>

Figure 1. Rivastigmin $\left(\right.$ Exelon $\left.^{\circledR}\right)$ - a drug for treatment of Alzheimer’s disease. ${ }^{5}$

In Alzheimer's disease, there is a severe loss of cholinergic cells in the brain that leads to diminished levels of the neurotransmitter acetylcholine (ACH). ${ }^{6}$ The pharmacology of CHEIs has been recently reviewed. ${ }^{5}$

Another medical application of carbamates consists in utilization of the so-called labile carbamate bond as connecting link between a polymeric carrier and medical drug. ${ }^{7}$ For example $^{7 \mathrm{a}}$, in the antimycotic conjugate of amphotericin B with star poly(ethylene glycol), amphotericin B was linked through a phenyl- $\beta$-D-glucopyranoside fragment by the labile carbamate linkage. Enzymatic hydrolysis of the $\beta$-glucosidic bond is followed by 1,6-elimination reaction and decomposition of carbamate linkage whereby amphotericin B is released from its polymeric carrier. This system was suggested for targeting therapy of systemic mycoses (Scheme 1).

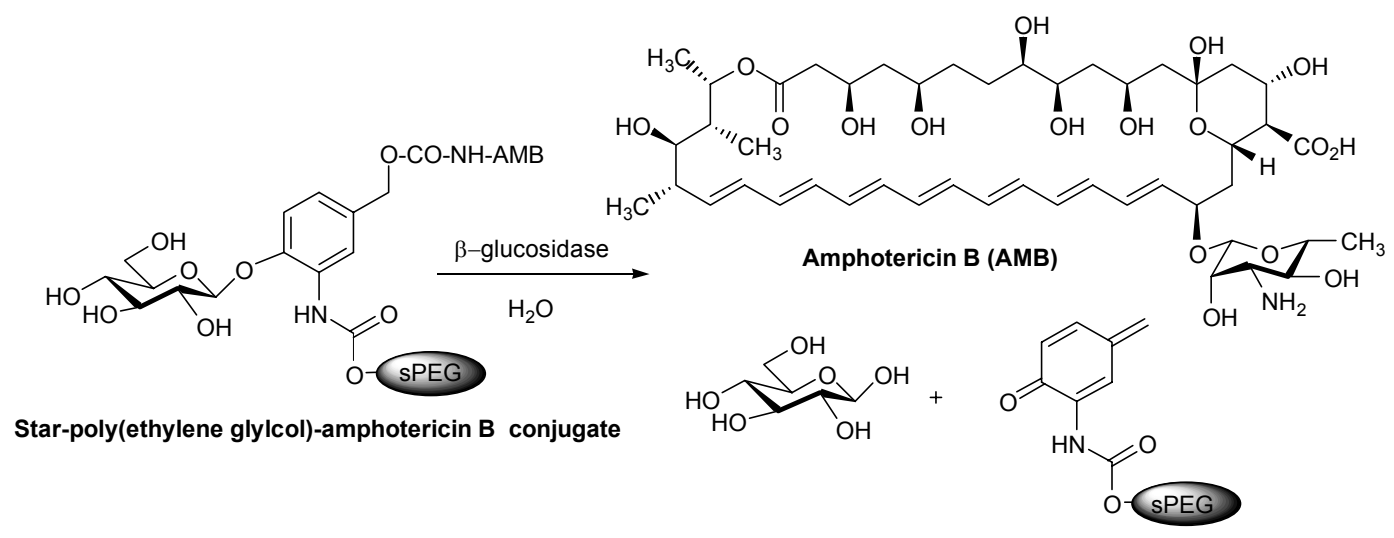

Scheme 1. 1,6-Benzyl elimination in targeting release of amphotericin B from polymeric carrier (star poly(ethylene glycol). ${ }^{7 \mathrm{a}}$

Although the 1,4- and 1,6-elimination reactions of benzyl carbamates are well known for a long time $\mathrm{e}^{7 \mathrm{~b}}$ and often used ${ }^{7 \mathrm{a}, \mathrm{c}, \mathrm{d}}$ for controlled drug release from polymeric carriers, the literature lacks a more detailed kinetic study of mechanism of this reaction. The aim of the present work is to study hydrolysis and methanolysis of benzyl $N$-phenylcarbamates 1a-k (Scheme 2). 


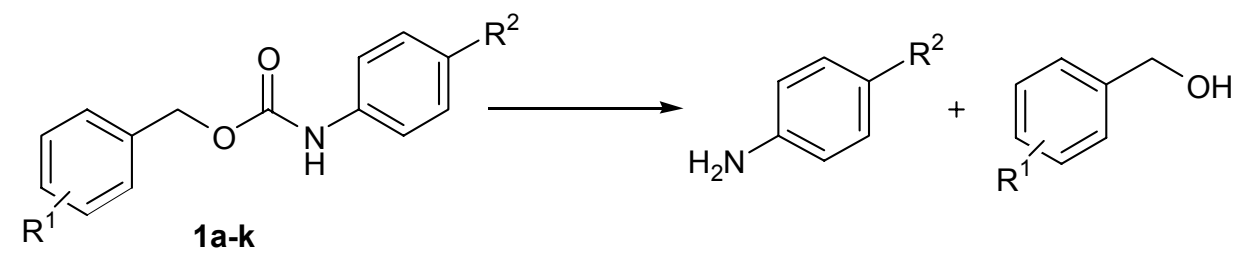

Scheme 2. Solvolysis of benzyl $N$-phenylcarbamates 1a-k; a: $\mathrm{R}^{1}=4-\mathrm{OCOCH}_{3}, \mathrm{R}^{2}=\mathrm{H} ; \mathbf{b}: \mathrm{R}^{1}=$ $4-\mathrm{OCOCH}_{3}, \mathrm{R}^{2}=\mathrm{NO}_{2} ; \mathbf{c}: \mathrm{R}^{1}=4-\mathrm{OCOCH}_{3}, \mathrm{R}^{2}=\mathrm{OCH}_{3} ; \mathbf{d}: \mathrm{R}^{1}=4-\mathrm{Cl}, \mathrm{R}^{2}=\mathrm{H} ; \mathbf{e}: \mathrm{R}^{1}=4-\mathrm{Cl}, \mathrm{R}^{2}=$ $\mathrm{NO}_{2} ; \mathbf{f}: \mathrm{R}^{1}=4-\mathrm{Cl}, \mathrm{R}^{2}=\mathrm{OCH}_{3} ; \mathbf{g}: \mathrm{R}^{1}=4-\mathrm{NO}_{2}, \mathrm{R}^{2}=\mathrm{H} ; \mathbf{h}: \mathrm{R}^{1}=4-\mathrm{NO}_{2}, \mathrm{R}^{2}=\mathrm{NO}_{2} ; \mathbf{i}: \mathrm{R}^{1}=4-$ $\mathrm{OCH}_{3}, \mathrm{R}^{2}=\mathrm{H} ; \mathbf{j}: \mathrm{R}^{1}=3-\mathrm{OPh}, \mathrm{R}^{2}=\mathrm{H} ; \mathbf{k}: \mathrm{R}^{1}=3-\mathrm{OPh}, \mathrm{R}^{2}=\mathrm{OCH}_{3}$.

Since it can also be presumed ${ }^{5,6}$ that benzyl esters of $N$-phenylcarbamic acid can be effective inhibitors of ACHE and BCHE, another aim of this work was to test the inhibition activity of the carbamates 1a-k and evaluate their possible therapeutic potential in the treatment of Alzheimer's disease.

\section{Results and Discussion}

From the structural formula (Fig. 2) of the carbamates (1a-c) possessing an acetoxy group at 4position of benzylic moiety it can be generally deduced that there will be four sites of attack by hydroxide or methoxide anion.

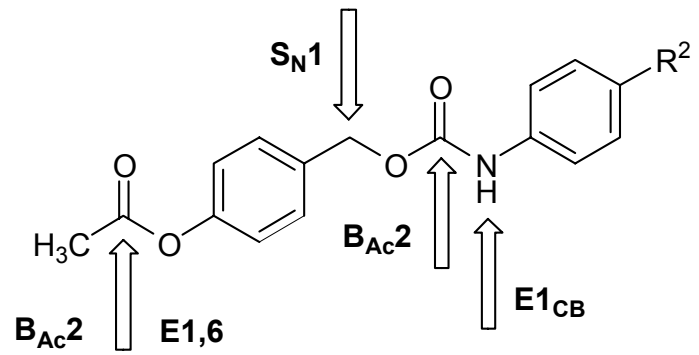

Figure 2. Possible sites of attack by hydroxide or methoxide anion in carbamates 1a-c.

The first possible site of attack is the carbonyl carbon atom in the acetoxy group in position 4- i.e. hydroxide- or methoxide-ion-catalyzed solvolysis of the ester bond $\left(\mathrm{B}_{\mathrm{Ac}} 2\right)$ with subsequent 1,6-elimination. The second reaction can be an $\mathrm{S}_{\mathrm{N}} 1$ reaction at the benzylic carbon atom. This possibility is less probable due to the low dielectric constant of the methanol. The third site of attack is the carbon atom of carbamate bond, where the $\mathrm{B}_{\mathrm{Ac}} 2$ solvolysis is possible too. In the case of strong electron-withdrawing groups $\left(\mathrm{R}^{2}\right)$, such as a nitro group, it is also possible to consider the $\mathrm{E} 1_{\mathrm{CB}}$ mechanism. 
First, we verified the possibility of spectrophotometric monitoring of the hydrolysis kinetics of carbamates 1a-c in sodium hydroxide solutions in the concentration range of $0.01-0.10 \mathrm{~mol} \cdot \mathrm{l}^{-1}$ at the temperature of $25^{\circ} \mathrm{C}$. It was found that in all the cases the starting carbamates are decomposed to give 4-hydroxybenzyl alcohol and sodium salts of substituted $\mathrm{N}$-phenylcarbamic acids. However it was impossible to precisely evaluate kinetic records due to turbidity or opalescence which was always formed at the substrate concentrations above $1 \times 10^{-5} \mathrm{~mol} \cdot \mathrm{l}^{-1}$. Therefore, we studied methanolysis in sodium methoxide solutions in the concentration range of $0.01-0.10 \mathrm{~mol} \cdot \mathrm{l}^{-1}$ at the temperature of $25^{\circ} \mathrm{C}$. In these cases the reactions proceeded in homogeneous medium, and the Lambert-Beer law was also fulfilled. The methanolyses were measured under pseudo-first order conditions when the system kinetically behaved as a single reaction $(\mathrm{A} \rightarrow \mathrm{B})$. Figure 3 presents the dependences of the observed rate constants $k_{\mathrm{obs}}\left(\mathrm{s}^{-1}\right)$ on the sodium methoxide concentration for the methanolyses of carbamates 1a-c and 2a-c.

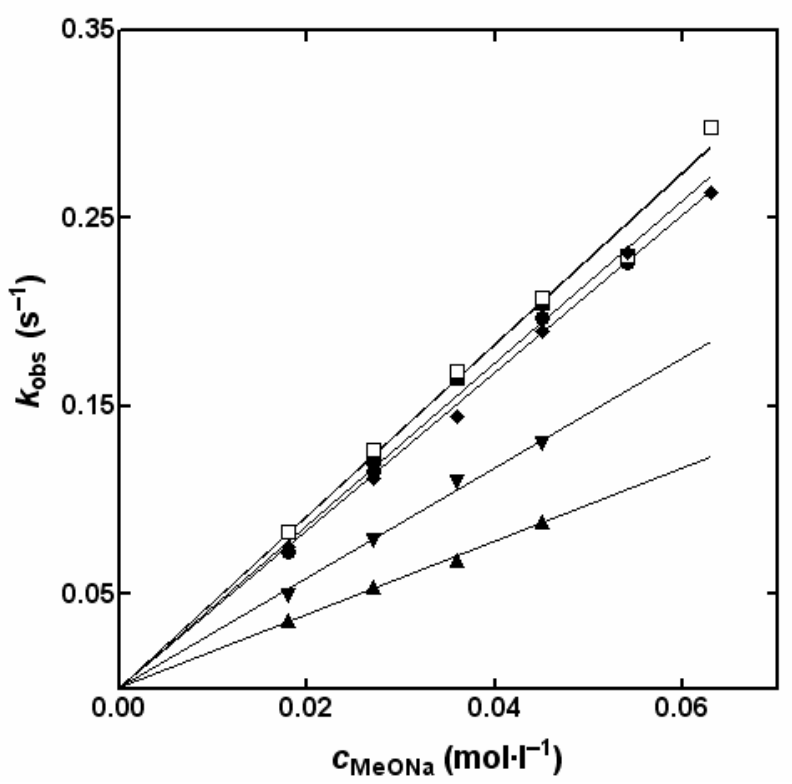

Figure 3. Dependence of the observed rate constants $k_{\mathrm{obs}}\left(\mathrm{s}^{-1}\right)$ on the sodium methoxide concentration $\left(\mathrm{mol} \cdot \mathrm{l}^{-1}\right)$ for methanolyses of derivatives: $\mathbf{1 a}-\bullet, \mathbf{1 b}-\square, \mathbf{1 c}-\bullet, \mathbf{2 a}-\mathbf{\Lambda}, \mathbf{2 b}-\boldsymbol{\nabla}$, $2 \mathrm{c}-\mathbf{n}$.

The graph shows that all the dependences are linear with relatively small differences in slopes between the individual carbamates 1a-c. The reaction order in methoxide ion is one. The reaction rate $v\left(\mathrm{~mol} \cdot l^{-1} \cdot \mathrm{s}^{-1}\right)$ and the observed rate constant $k_{\mathrm{obs}}\left(\mathrm{s}^{-1}\right)$ could be expressed by the following equations, where $c_{\mathrm{s}}$ stands for concentration of substrate $\left(\mathrm{mol} \cdot l^{-1}\right), k\left(\mathrm{~mol}^{-1} \cdot 1 \cdot \mathrm{s}^{-1}\right)$ is the catalytic constant of decomposition of ester, $\left[\mathrm{CH}_{3} \mathrm{O}^{-}\right]$is actual concentration of methoxide ion:

$$
v=k_{\text {obs }} c_{\mathrm{s}} ; k_{\mathrm{obs}}=k\left[\mathrm{CH}_{3} \mathrm{O}^{-}\right]
$$

Plotting of $k$ values of the individual carbamates $\left(\mathbf{1 a :} k=4.20 \mathrm{~mol}^{-1} \cdot 1 \cdot \mathrm{s}^{-1}, \mathbf{1 b}: k=4.61 \mathrm{~mol}^{-}\right.$ ${ }^{1} \cdot 1 \cdot \mathrm{s}^{-1}$ 1c: $k=4.27 \mathrm{~mol}^{-1} \cdot 1 \cdot \mathrm{s}^{-1}$ ) against the Hammett substituent constants $\sigma$ gave a linear 
dependence with slope practically equal to zero, which indicates that the attack by methoxide ion must take place far from the substituent, hence on the carbonyl carbon atom of acetoxy group. This means that either the initial methanolysis of ester linkage $\left(\mathrm{B}_{\mathrm{Ac}} 2\right)$ is followed by 1,6elimination giving the reactive 1,4-quinonemethide (Scheme 3); or alternatively a concerted mechanism combines the attack by methoxide ion with simultaneous cleavage of the bond between carbon atom and phenoxide oxygen atom (Scheme 4).<smiles>[R]c1ccc(NC(=O)OCc2ccc(OC(C)([O-])OC)cc2)cc1</smiles><smiles></smiles><smiles>COCc1ccc([O-])cc1</smiles>

Scheme 3. Two-step mechanism $\left(\mathrm{B}_{\mathrm{Ac}} 2\right)$ for methanolysis of derivatives 1a-c.<smiles>[R]c1ccc(NC(=O)OCc2ccc(NC(=O)OCC(C)C(C)C)cc2)cc1</smiles>

Scheme 4. One-step (concerted) mechanism for methanolysis of derivatives 1a-c.

The presence of 1,4-quinonemethide formed was proved by analysis of the reaction products. In these cases mass spectrometry proved the presence of 4-methoxymethylphenol, i.e. product of addition of methanol to 1,4-quinonemethide. The same conditions as those used in the cases of carbamates 1a-c were also adopted in the study of methanolysis of 4-methylphenyl acetate (2a), 4-hydroxymethylphenyl acetate (2b), and 4-acetoxymethylphenyl acetate (2c). In 
the cases of methanolyses of esters $\mathbf{2 a}$ and $\mathbf{2 b}$, methyl acetate is produced along with sodium phenoxide and sodium 4-hydroxymethylphenoxide, respectively. In the case of 4acetoxymethylphenyl acetate (2c), methyl acetate is produced along with sodium 4methoxymethylphenoxide. The kinetic dependences presented in Fig. 3 show that the methanolysis of 4-methylphenyl acetate (2a) is the slowest: $k=1.96 \mathrm{~mol}^{-1} \cdot 1 \cdot \mathrm{s}^{-1}$. Also the methanolysis of 4-hydroxymethylphenyl acetate $(\mathbf{2 b})$ is slower $\left(k=2.93 \mathrm{~mol}^{-1} \cdot 1 \cdot \mathrm{s}^{-1}\right)$ than that of 4-acetoxymethylphenyl acetate $(2 \mathrm{c})\left(k=4.56 \mathrm{~mol}^{-1} \cdot 1 \cdot \mathrm{s}^{-1}\right)$, where the dependence of the observed rate constant on the methoxide concentration lies at a virtually identical straight line as that for carbamates 1a-c (Fig. 3). The formation of 1,4-quinonemethide and practically the same kinetic dependence indicate that the methanolysis of 4-acetoxymethylphenyl acetate (2c) will proceed by a mechanism similar to that operating in the cases of carbamates 1a-c. From the literature ${ }^{8}$ it is known that the methanolysis of phenyl acetates proceeds by the $\mathrm{B}_{\mathrm{Ac}} 2$ mechanism in which the rate-limiting (the slowest) reaction step involves addition of methoxide ion with formation of a tetrahedral intermediate, which is rapidly decomposed in the second reaction step to give phenoxide anion. The acceleration of methanolysis of 4-acetoxymethylphenyl acetate (2c), as compared with 4-methylphenyl acetate (2a) and 4-hydroxymethylphenyl acetate (2b), can be explained with high probability by operation of concerted mechanism. This means that the attack by methoxide ion and the cleavage of the bond between carbon atom and phenoxide oxygen atom are simultaneous processes. This process involves delocalization of negative charge with concomitant lowering of the transition state energy and acceleration of methanolysis in comparison with the other acetates.

Moreover, we studied the methanolysis of carbamates 1d-f i.e. carbamates having 4-Cl substituent in the benzyl moiety; the Hammett $\sigma$ constant $^{9}$ of this substituent $(0.22)$ is close to that of acetoxy group (0.31), but the methanolysis of these carbamates cannot involve 1,6elimination; it can proceed only by the $\mathrm{B}_{\mathrm{Ac}} 2$ or $\mathrm{E} 1_{\mathrm{CB}}$ mechanism on the carbamate group. However, in all the cases it was found that these carbamates are relatively stable in this medium, and the methanolysis under given conditions does not take place. From this observation it is clear that the $\mathrm{B}_{\mathrm{Ac}} 2$ or $\mathrm{E} 1_{\mathrm{CB}}$ mechanisms on the carbamate group will not operate in the case of carbamates 1a-c either.

Also methanolyses of 4-nitrobenzyl $N$-phenylcarbamate (1g) and 4-nitrobenzyl $N$-4nitrophenylcarbamate (1h) were investigated, i.e. carbamates carrying a nitro group instead of acetoxy or chloro substituent. Carbamate $1 \mathrm{~g}$ was found to be relatively stable in the said media, whereas carbamate $\mathbf{1 h}$ undergoes methanolysis at a measurable rate $\left(k_{\mathrm{obs}}=4.58 \times 10^{-2} \mathrm{~s}^{-1}\right.$ for sodium methoxide, $\left.c=0.036 \mathrm{~mol} \cdot \mathrm{l}^{-1}\right)$. However, this finding cannot decide to what extent the individual mechanisms $\left(\mathrm{B}_{\mathrm{Ac}} 2\right.$ or $\left.\mathrm{E} 1 \mathrm{cb}\right)$ are operating.

As already stated, the methanolysis of carbamates 1a-c produces a very reactive intermediate 1,4-quinonemethide which reacts with nucleophiles present: hydroxide, methoxide or others. This fact can be useful in the case of potential ACHE inhibitors, because one of the principles of ACHE inhibition lies in alkylation of nucleophilic functional groups in active sites of ACHE. 
Acetylcholine is hydrolytically destroyed in the brain by cholinesterases. ${ }^{10}$ In vertebrates, there are two types of cholinesterases, which are distinguished on the basis of their substrate specificities, distribution in various tissues and sensitivity toward various inhibitors. There exist acetylcholinesterase (true cholinesterase, specific cholinesterase, ACHE; E.C. 3.1.1.7) and butyrylcholinesterase (pseudocholinesterase, non-specific cholinesterase, BCHE; E.C. 3.1.1.8). ${ }^{11}$ The effectiveness of the inhibitor could be described by the $50 \%$ inhibitory concentration $\mathrm{IC}_{50}$. Table 1 summarizes values of the $50 \%$ inhibitory concentration $\mathrm{IC}_{50}$ and partition coefficients $\mathrm{P}_{\mathrm{ow}}$ of tested carbamates 1a-k.

Table 1. The $\mathrm{IC}_{50}$ values and partition coefficient $\mathrm{P}_{\mathrm{ow}}$ of carbamates $\mathbf{1 a - k}$

\begin{tabular}{cccccccccccc}
\hline & \multicolumn{10}{c}{ Carbamate $/ \mathrm{IC}_{50}\left[\mu \mathrm{mol} \cdot \mathrm{l}^{-1}\right]$} \\
& 1a & 1b & 1c & $\mathbf{1 d}$ & $\mathbf{1 e}$ & $\mathbf{1 f}$ & $\mathbf{1 g}$ & $\mathbf{1 h}$ & $\mathbf{1 i}$ & $\mathbf{1 j}$ & $\mathbf{1 k}$ \\
\hline $\mathrm{ACHE}$ & 199.3 & 311.6 & 412.3 & 292.5 & 252.3 & 390.3 & 235.2 & 442.1 & 428.3 & 315.8 & 534.9 \\
$\mathrm{BCHE}$ & 20.5 & 44.6 & 50.4 & 31.6 & 52.3 & 74.2 & 49.9 & 148.1 & 62.6 & 149.7 & 176.8 \\
$\mathrm{P}_{\mathrm{ow}}$ & 2.21 & 2.97 & 3.15 & 2.71 & 4.32 & 7.26 & 1.51 & 4.54 & 9.99 & 8.24 & 11.51 \\
\hline
\end{tabular}

From the results obtained it follows that all the tested carbamates 1a-k inhibit ACHE as well as BCHE. Generally it is possible to conclude that inhibition of BCHE by the tested compounds is stronger than that of ACHE. The effectiveness of tested carbamates 1a-j for inhibition of ACHE is higher than that of Exelon ${ }^{\circledR}$ (ACHE: $\mathrm{IC}_{50}=501 \mu \mathrm{mol} \cdot \mathrm{l}^{-1}$ ). ${ }^{12 \mathrm{a}}$ On the other hand, the effectiveness of all the tested carbamates for inhibition of $\mathrm{BCHE}$ is lower than that of Exelon ${ }^{\circledR}$ $\left(\mathrm{BCHE}: \mathrm{IC}_{50}=20 \mu \mathrm{mol} \cdot \mathrm{l}^{-1}\right.$ ). ${ }^{12 \mathrm{a}}$ This could be caused by several structural differences between the hydrophobic gorge of active centre in ACHE and that in BCHE. At the base of the gorge in $\mathrm{ACHE}$, the binding of the substrate is represented by two phenylalanine molecules whose aromatic residues protrude into the gorge. ${ }^{13}$ In $\mathrm{BCHE}$, these molecules are replaced by two smaller amino acid molecules, such as valine and leucine. This conformational change creates a larger space within the deepest area of the gorge of BCHE to allow the fit of larger-size substrates and inhibitors of BCHE. ${ }^{14}$ The most effective inhibitor of ACHE and BCHE is compound 1a. The worst inhibitor is compound $\mathbf{1 k}$. The values of partition coefficient showed that the tested carbamates 1a-k are much better soluble in $n$-octanol than in water and that is why the potential for crossing the blood-brain barrier should be good.

\section{Experimental Section}

General Procedures. The starting chemicals were purchased from Sigma-Aldrich. Methanol (UV-Vis grade) was refluxed under argon to remove traces of carbon dioxide and stored under argon atmosphere. Its quality was checked by means of UV VIS spectroscopy. Absorbance of the pure solvent against empty cell was lower than 0.08 in the wavelength range above $\lambda=250 \mathrm{~nm}, l$ $=1 \mathrm{~cm}$. The given melting points were not corrected. Structures of the products prepared were 
verified by means of ${ }^{1} \mathrm{H}$ and ${ }^{13} \mathrm{C}$ NMR. The ${ }^{1} \mathrm{H}$ and ${ }^{13} \mathrm{C}$ NMR spectra were recorded on a Bruker Avance 500 instrument. The chemical shifts $\delta$ are referenced to the solvent residual peaks $\delta\left(\right.$ DMSO- $\left.d_{6}\right)=2.55 \mathrm{ppm}\left({ }^{1} \mathrm{H}\right)$ and $39.6 \mathrm{ppm}\left({ }^{13} \mathrm{C}\right)$. The coupling constants $J$ are given in Hz. The mass spectra were recorded on an Agilent Technologies Comp. gas chromatograph $6890 \mathrm{~N}$ with a mass detector 5973 Network for samples dissolved in either ether or acetone. The microanalyses were performed on an apparatus of FISONS Instruments, EA 1108 CHN.

The kinetic measurements were carried out using HP UV/VIS 8453 Diode Array apparatus in 1$\mathrm{cm}$ quartz closable cell at $25^{\circ} \mathrm{C}$. At this temperature, $10 \mu 1$ methanolic solution of substrate was injected into $2 \mathrm{ml}$ aqueous sodium hydroxide or methanolic sodium methoxide, so that the final concentration of substrate was ca $5 \times 10^{-4} \mathrm{~mol} \cdot \mathrm{l}^{-1}$. The measured absorbance-time dependences at appropriate wavelength (1a,b and $\mathbf{2 b , c}$ at $245 \mathrm{~nm}$; 1c: $292 \mathrm{~nm} ; \mathbf{2 a}: 240 \mathrm{~nm}$ ) were used to calculate the observed rate constant $k_{\mathrm{obs}}$ using an optimizing program.

The $\mathrm{IC}_{50}$ values were determined by the method of initial reaction rates. ${ }^{12}$ The determination of partition coefficient $\left(\mathrm{P}_{\text {ow }}\right)$ in $n$-octanol/water system was carried out by a known method. ${ }^{15}$

\section{General method of preparation of substituted $\mathrm{N}$-phenyl- $\mathrm{O}$-benzylcarbamates (1a-1k)}

A solution of corresponding substituted benzyl alcohol $(2.5 \mathrm{mmol})$ with 2 drops of triethylamine in chloroform $(5 \mathrm{ml})$ was treated with a solution of corresponding substituted phenyl isocyanate $(2.5 \mathrm{mmol})$ in chloroform $(5 \mathrm{ml})$. The separated solid was collected by filtration, dried and recrystallized from the below-given solvent.

4-(Phenylcarbamoyloxymethyl)phenyl acetate (1a). Yield: $65 \%$, m.p. $96-99{ }^{\circ} \mathrm{C}$ (chloroform/ethyl acetate). ${ }^{1} \mathrm{H}$ NMR: 2.27 (s, 3H, $\left.\mathrm{CH}_{3}\right) ; 5.15\left(\mathrm{~s}, 2 \mathrm{H}, \mathrm{CH}_{2}\right) ; 6.99(\mathrm{t}, 1 \mathrm{H}, J=7.5$, Ar); 7.15 (d, 2H, $J=8.0, \mathrm{Ar}) ; 7.28$ (t, $2 \mathrm{H}, J=7.5, \operatorname{Ar}), 7.47$ (d, 4H, $J=8.0, \mathrm{Ar}) ; 9.77$ (s, $1 \mathrm{H}$, NH). ${ }^{13}$ C NMR: $20.8 ; 65.1 ; 118.1 ; 121.8 ; 122.4 ; 128.7 ; 129.3 ; 134.1 ; 139.0 ; 150.1 ; 153.2 ; 169.2$. EI-MS (m/z ): 285, 241, 207, 166, 149, 119, 107, 91, 77, 64. Anal. calcd. for $\mathrm{C}_{16} \mathrm{H}_{15} \mathrm{NO}_{4}$ (285.29): C, 67.36; H, 5.30; N, 4.91; found: C, 67.59; H, 5.48; N, 5.10.

4-(4-Nitrophenylcarbamoyloxymethyl)phenyl acetate (1b). Yield: $45 \%$, m.p. $164-166{ }^{\circ} \mathrm{C}$ (methanol/ethyl acetate). ${ }^{1} \mathrm{H}$ NMR: $2.27\left(\mathrm{~s}, 3 \mathrm{H}, \mathrm{CH}_{3}\right) ; 5.20\left(\mathrm{~s}, 2 \mathrm{H}, \mathrm{CH}_{2}\right) ; 7.16(\mathrm{~d}, 2 \mathrm{H}, J=8.5$, Ar); 7.50 (d, $2 \mathrm{H}, J=8.5, \mathrm{Ar}) ; 7.70$ (d, 2H, $J=9.5, \mathrm{Ar}), 8.20$ (d, 2H, $J=9.5, \mathrm{Ar}) ; 10.52$ (s, $1 \mathrm{H}$, NH). ${ }^{13} \mathrm{C}$ NMR: $20.8 ; 65.9 ; 117.6 ; 121.9 ; 125.0 ; 129.6 ; 133.5 ; 141.7 ; 145.5 ; 150.3 ; 153.0 ; 169.2$. Anal. calcd. for $\mathrm{C}_{16} \mathrm{H}_{14} \mathrm{~N}_{2} \mathrm{O}_{6}$ (330.29): C, 68.18; H, 4.27; N, 8.48; found: $\mathrm{C}, 68.28 ; \mathrm{H}, 4.39 ; \mathrm{N}$, 8.56 .

4-(4-Methoxyphenylcarbamoyloxymethyl)phenyl acetate (1c). Yield: $60 \%$, m.p. $129-131{ }^{\circ} \mathrm{C}$ (chloroform/ethyl acetate). ${ }^{1} \mathrm{H}$ NMR: $2.27\left(\mathrm{~s}, 3 \mathrm{H}, \mathrm{CH}_{3}\right) ; 3.70\left(\mathrm{~s}, 3 \mathrm{H}, \mathrm{CH}_{3}\right) ; 5.12\left(\mathrm{~s}, 2 \mathrm{H}, \mathrm{CH}_{2}\right) ; 6.86$ (d, $2 \mathrm{H}, J=9.0, \mathrm{Ar}$ ); 7.14 (d, 2H, $J=8.0$, Ar); 7.36 (d, 2H, $J=8.0$, Ar), 7.46 (d, $2 \mathrm{H}, J=9.0$, Ar); $9.57(\mathrm{~s}, 1 \mathrm{H}, \mathrm{NH}) .{ }^{13} \mathrm{C}$ NMR: $20.8 ; 55.1 ; 65.0 ; 113.9 ; 119.7 ; 121.8 ; 129.3 ; 132.0 ; 134.2$; 150.1; 153.4; 154.7; 169.1. EI-MS (m/z ): 315, 271, 207, 166, 149, 134, 124, 107, 95, 78, 63, 52, 43. Anal. calcd. for $\mathrm{C}_{17} \mathrm{H}_{17} \mathrm{NO}_{5}$ (315.32): $\mathrm{C}, 64.75 ; \mathrm{H}, 5.43 ; \mathrm{N}, 4.44$; found: $\mathrm{C}, 64.88 ; \mathrm{H}, 4.42 ; \mathrm{N}$, 4.50 . 
4-Chlorobenzyl $N$-phenylcarbamate (1d). Yield: $60 \%$, m.p. $88-89{ }^{\circ} \mathrm{C}$ (chloroform/ethyl acetate). ${ }^{1} \mathrm{H}$ NMR: 5.15 (s, 2H, $\left.\mathrm{CH}_{2}\right) ; 6.99$ (t, 1H, $J=10.5$, Ar); 7.28 (t, 2H, $J=10.5 \mathrm{Ar}$ ); 7.47 $(\mathrm{m}, 6 \mathrm{H}, \mathrm{Ar}) ; 9.80(\mathrm{~s}, 1 \mathrm{H}, \mathrm{NH}) .{ }^{13} \mathrm{C} \mathrm{NMR}\left(\mathrm{DMSO}-d_{6}\right): 64.8 ; 118.1 ; 122.4 ; 128.4 ; 128.7 ; 129.8$; 132.6; 135.6; 138.9; 153.2. EI-MS (m/z): 261, 217, 182, 142, 125, 119, 107, 91, 77, 64, 51. Anal. calcd. for $\mathrm{C}_{14} \mathrm{H}_{12} \mathrm{ClNO}_{2}$ (261.06): C, 64.25; H, 4.62; Cl, 13.55; N, 5.34; found: C, 64.08; H, 4.72; Cl, 13.52; N, 5.50.

4-Chlorobenzyl $\quad \boldsymbol{N}$-4-nitrophenylcarbamate (1e). Yield: $66 \%$, m.p. $215-216 \quad{ }^{\circ} \mathrm{C}$ (tetrahydrofuran/ethyl acetate). ${ }^{1} \mathrm{H}$ NMR: 5.19 (s, 2H, $\left.\mathrm{CH}_{2}\right) ; 7.46$ (m, 4H, Ar); 7.69 (t, 2H, J= 9.5, Ar); 8.19 (d, 2H, $J=9.5$, Ar); 10.54 (s, 1H, NH). ${ }^{13} \mathrm{C}$ NMR 65.5; 117.6; 125.0; 128.5; 130.1; 132.8; 135.1; 141.7; 145.4; 152.9. Anal. calcd. for $\mathrm{C}_{14} \mathrm{H}_{11} \mathrm{ClN}_{2} \mathrm{O}_{4}(306.04)$ : C, 54.83; $\mathrm{H}, 3.62 ; \mathrm{Cl}$, 11.56; N, 9.13; found: C, 54.68; H, 3.72; Cl, 11.50; N, 9.22.

4-Chlorobenzyl $\mathbf{N}$-4-methoxyphenylcarbamate (1f). Yield: $71 \%, \quad$ m.p. $122-124{ }^{\circ} \mathrm{C}$ (tetrahydrofuran/ethyl acetate). ${ }^{1} \mathrm{H} \mathrm{NMR}: 3.70\left(\mathrm{~s}, 3 \mathrm{H}, \mathrm{CH}_{3}\right) ; 5.12\left(\mathrm{~s}, 2 \mathrm{H}, \mathrm{CH}_{2}\right) ; 6.86(\mathrm{~d}, 2 \mathrm{H}, J=$ 9.0, Ar); 7.37 (d, 2H, $J=7.5, \mathrm{Ar}), 7.46$ (m, 4H, Ar); 9.61 (s, 1H, NH). ${ }^{13} \mathrm{C}$ NMR: 55.1; 64.7; $113.9 ; 119.7 ; 128.4 ; 129.8 ; 132.0 ; 132.5 ; 135.8 ; 153.3 ; 154.8$. EI-MS (m/z): 291, 247, 149, 134, 125, 106, 89, 77, 63, 51. Anal. calcd. for $\mathrm{C}_{15} \mathrm{H}_{14} \mathrm{ClNO}_{3}$ (291.07): C, 61.76; H, 4.84; Cl, 12.15; N, 4.80; found: C, 61.64; H, 4.76; Cl, 12.04; N, 5.01.

4-Nitrobenzyl $\mathrm{N}$-phenylcarbamate (1g). Yield: 50\%, m.p. 123-125 ${ }^{\circ} \mathrm{C}$ (chloroform/ethyl acetate), (124-125 $\left.{ }^{\circ} \mathrm{C}\right) .{ }^{16}{ }^{1} \mathrm{H}$ NMR: 5.30 (s, 2H, $\left.\mathrm{CH}_{2}\right) ; 7.00$ (m, 1H, Ar); 7.28 (m, 2H, Ar); 7.48 $(\mathrm{d}, 2 \mathrm{H}, J=8.5, \mathrm{Ar}) ; 7.69(\mathrm{~d}, 2 \mathrm{H}, J=8.5, \mathrm{Ar}) ; 8.27(\mathrm{~m}, 2 \mathrm{H}, \mathrm{Ar}) ; 9.91(1 \mathrm{H}, \mathrm{s}, \mathrm{NH}) .{ }^{13} \mathrm{C} \mathrm{NMR}$ : $64.4 ; 118.1 ; 122.5 ; 123.6 ; 128.4 ; 128.7 ; 138.8 ; 144.5 ; 147.0 ; 153.0$. Anal. calcd. for $\mathrm{C}_{14} \mathrm{H}_{12} \mathrm{~N}_{2} \mathrm{O}_{4}$ (272.26): C, 61.76; H, 4.44; N, 10.29; found: C, 61.96; H, 4.48; N, 10.02 .

4-Nitrobenzyl $\quad \boldsymbol{N}$-4-nitrophenylcarbamate (1h). $\quad$ Yield: $\quad 72 \%, \quad$ m.p. $\quad 225-227 \quad{ }^{\circ} \mathrm{C}$ (tetrahydrofuran/ethyl acetate). ${ }^{1} \mathrm{H}$ NMR: $5.36\left(\mathrm{~s}, 2 \mathrm{H}, \mathrm{CH}_{2}\right) ; 7.71(\mathrm{~m}, 4 \mathrm{H}, \mathrm{Ar}) ; 8.22(\mathrm{~d}, 2 \mathrm{H}, J=$ 9.5, Ar); 8.27 (d, 2H, $J=9.0, \mathrm{Ar}) ; 10.65$ (s, 1H, NH). ${ }^{13} \mathrm{C} \mathrm{NMR}: 65.0 ; 117.7 ; 123.5 ; 125.0$; 128.6; 141.7; 143.8; 145.3; 147.1; 152.7. Anal. calcd. for $\mathrm{C}_{14} \mathrm{H}_{11} \mathrm{~N}_{3} \mathrm{O}_{6}$ (317.25): C, 53.00; $\mathrm{H}$, 3.49 ; N, 13.24; found: C, 53.22; H, 3.67; N, 13.22 .

4-Methoxybenzyl $\mathbf{N}$-phenylcarbamate (1i). Yield: $40 \%$, m.p. $88-90{ }^{\circ} \mathrm{C}$ (tetrahydrofuran/ethyl acetate), $\left(91-92{ }^{\circ} \mathrm{C}\right) .{ }^{17}{ }^{1} \mathrm{H}$ NMR: $3.75\left(\mathrm{~s}, 3 \mathrm{H}, \mathrm{CH}_{3}\right) ; 5.07\left(\mathrm{~s}, 2 \mathrm{H}, \mathrm{CH}_{2}\right) ; 6.95(\mathrm{~m}, 2 \mathrm{H}, \mathrm{Ar}) ; 6.98$ (m, 1H, Ar); 7.27 (m, 2H, Ar); 7.37 (d, 2H, $J=8.5$, Ar); 7.47 (d, 2H, J=8.5, Ar); 9.70 (s, 1H, NH). ${ }^{13}$ C NMR: $55.1 ; 65.5 ; 113.8 ; 118.1 ; 122.3 ; 128.4 ; 128.7 ; 130.0 ; 139.1 ; 153.4 ; 159.1$. Anal. calcd. for $\mathrm{C}_{15} \mathrm{H}_{15} \mathrm{NO}_{3}$ (257.28): C, 70.02; H, 5.84; N, 5.44; found: C, 70.11; H, 5.94; N, 5.46.

3-Phenoxybenzyl $\mathrm{N}$-phenylcarbamate (1j). Yield: $66 \%$, m.p. $69-71{ }^{\circ} \mathrm{C}$ (tetrahydrofuran/ethyl acetate), $\left(71{ }^{\circ} \mathrm{C}\right) .{ }^{18}{ }^{1} \mathrm{H}$ NMR: $5.19\left(\mathrm{~s}, 2 \mathrm{H}, \mathrm{CH}_{2}\right) ; 7.02-7.53(\mathrm{~m}, 14 \mathrm{H}, \mathrm{Ar}) ; 9.83(\mathrm{~s}, 1 \mathrm{H}, \mathrm{NH}) .{ }^{13} \mathrm{C}$ NMR: $65.2 ; 117.9 ; 118.1 ; 118.3 ; 118.7 ; 122.5 ; 122.9 ; 123.6 ; 128.8 ; 130.1 ; 139.0 ; 153.3 ; 156.5$; 156.8. Anal. calcd. for $\mathrm{C}_{20} \mathrm{H}_{17} \mathrm{NO}_{3}$ (319.35): C, 75.22; H, 5.37; N, 4.39; found: C, 75.29; H, 5.47; $\mathrm{N}, 4.45$.

3-Phenoxybenzyl $\quad N$-4-methoxyphenylcarbamate (1k). Yield: $68 \%$, m.p. 88-89 ${ }^{\circ} \mathrm{C}$ (methanol/ethyl acetate). ${ }^{1} \mathrm{H}$ NMR: $3.70\left(\mathrm{~s}, 3 \mathrm{H}, \mathrm{CH}_{3}\right) ; 5.12\left(\mathrm{~s}, 2 \mathrm{H}, \mathrm{CH}_{2}\right) ; 6.86(\mathrm{~m}, 2 \mathrm{H}, \mathrm{Ar}) ; 6.96$ (m, 1H, Ar); 7.02 (m, 2H, Ar); 7.07 (m, 1H, Ar); 7.16 (m, 2H, Ar); 7.38 (m, 5H, Ar); 9.59 (brs, 
$1 \mathrm{H}, \mathrm{NH}) .{ }^{13} \mathrm{C}$ NMR: $55.1 ; 65.0 ; 99.3 ; 113.9 ; 117.8 ; 117.9 ; 118.6 ; 119.7 ; 122.7 ; 123.5 ; 130.0$; $130.1 ; 139.0 ; 153.3 ; 154.8 ; 156.4 ; 156.7$. Anal. calcd. for $\mathrm{C}_{21} \mathrm{H}_{19} \mathrm{NO}_{4}$ (349.38): C, 72.19; $\mathrm{H}, 5.48$; N, 4.01; found: C, 72.10; H, 5.61; N, 4.17.

\section{Trapping of 1,4-quinonemethide in the form of 4-methoxymethylphenol}

A solution of corresponding carbamate 1a-c $(0.05 \mathrm{mmol})$ in methanol $(5 \mathrm{ml})$ was treated with a solution of sodium methoxide $\left(20 \mu \mathrm{l}, 2.5 \mathrm{~mol} \cdot \mathrm{l}^{-1}\right)$. After $5 \mathrm{~min}$, the reaction mixture was neutralized with aqueous acetic acid and extracted with dichloromethane. The extract was evaporated, and the evaporation residue was analyzed by means of GC/MS. EI-MS (m/z): 138, $121,107,95,77,65,51,39$.

\section{Acylation of 4-hydroxybenzyl alcohol}

A cold solution $\left(0^{\circ} \mathrm{C}\right)$ of 4-hydroxybenzyl alcohol $(4.46 \mathrm{~g}, 40 \mathrm{mmol})$ and triethylamine $(5.6 \mathrm{ml}$, $40 \mathrm{mmol})$ in ethyl acetate $(75 \mathrm{ml})$ was stirred and treated with a solution of acetyl chloride (3.14 g, $40 \mathrm{mmol})$ in ethyl acetate $(30 \mathrm{ml})$ added drop by drop during $30 \mathrm{~min}$. After 1 hour stirring, the formed salt was removed by filtration, and the filtrate was distilled in vacuum at the temperature of $40^{\circ} \mathrm{C}$. The crude product mixture was separated by means of column chromatography (silica gel; chloroform/ethyl acetate $(1: 1))$.

4-Hydroxymethylphenyl acetate (2b). Yield: $28 \%$ (yellow oil), TLC: (silica gel plates, chloroform/ethyl acetate (1:1) $\mathrm{R}_{\mathrm{F}}=0.26 .{ }^{1} \mathrm{H} \mathrm{NMR}: 2.26\left(\mathrm{~s}, 3 \mathrm{H}, \mathrm{CH}_{3}\right) ; 4.53\left(\mathrm{~d}, 2 \mathrm{H}, J=6.0, \mathrm{CH}_{2}\right)$; 5.28 (t, $1 \mathrm{H}, J=6.0, \mathrm{CH}_{2} \mathrm{OH}$ ); 7.09 (d, $2 \mathrm{H}, J=8.0, \mathrm{Ar}$ ); 7.37 (d, $\left.2 \mathrm{H}, J=8.0, \mathrm{Ar}\right) .{ }^{13} \mathrm{C}$ NMR: 208; $62.4 ; 121.4 ; 127.5 ; 140.1 ; 149.2 ; 169.3$. EI-MS (m/z ): 166, 124, 106, 95, 77, 43. Anal. calcd. for $\mathrm{C}_{9} \mathrm{H}_{10} \mathrm{O}_{3}$ (166.17): C, 65.05; H, 6.07. Found: C, 64.85; H, 5.86.

4-Acetoxymethylphenyl acetate ${ }^{19}$ (2c). Yield: $43 \%$ (yellow oil), TLC: (silica gel plates, chloroform/ethyl acetate (1:1) $\mathrm{R}_{\mathrm{F}}=0.58$. EI-MS (m/z): 208, 166, 124, 107, 95, 78, 43.

\section{Acknowledgements}

The authors acknowledge the help of Jana Jedličková, MSc., in kinetic measurements and financial support from the Czech Ministry of Education, Youth and Sports, grants No. MSM 002 1627501 and MSM 0021627502.

\section{References}

1. (a) Ray, S.; Chaturvedi, D. Drugs Fut. 2004, 29, 343. (b) Ray, S.; Pathak, S. R.; Chaturvedi, D. Drugs Fut. 2005, 30, 161. (c) Mindl, J. Chem. Listy 2000, 94, 175.

2. Mikolaczyk, W.; Wawro, D.; Strusczyk, H. Fibres Text. East. Eur. 1998, 6, 53; Chem. Abstr. 1999, 130, 4757.

3. Fei, X.; Gao, P.; Shibamoto, T.; Sun, G. Arch. Environ. Contam. Toxicol. 2006, $51,509$. 
4. (a) Lawrence, M.; Klein, D. L.; Nemoto, P. Bioorg. Med. Chem. Lett. 1997, 7, 157. (b) BarOn, P., Millard, C. B.; Harel, M.; Dvir, H.; Enz, A.; Sussman, J. L.; Silman, I. Biochemistry 2002, 41, 3555. (c) Bartolucci, C.; Siotto, M.; Ghidini, E.; Amari, G.; Bolzoni, P. T.; Racchi, M.; Villetti, G.; Delcanale, M.; Lamba, D. J. Med. Chem. 2006, 49, 5051.

5. Dantoine, T.; Auriacombe, S.; Sarazin, M.; Becker, H.; Pere, J.- J.; Bourdeix, I. Int. J. Clin. Pract. 2006, 60, 110.

6. Amenta, F.; Parneti, L.; Gallai, V.; Wallin, A. Mech. Ageing Dev. 2001, 122, 2025.

7. (a) Sedlák, M.; Drabina, P.; Bílková, E.; Šimůnek, P.; Buchta, V. Bioorg. Med. Chem. Lett. 2008, 18, 2952. (b) Wakselman, M. Nouv. J. Chim. 1983, 7, 439. (c) Sedlák, M. Collect. Czech. Chem. Commun. 2005, 70, 269. (d) Greenwald, R. B.; Choe, Y. H.; McGurie, J.; Conover, C. D. Adv. Drug Delivery Rev. 2003, 55, 217.

8. Adams, P.; Baron, F. A. Chem. Rev. 1965, 65, 567.

9. Hansch, C.; Leo, A.; Taft, R. W. Chem. Rev. 1991, 91, 567.

10. Ellis, J. M. J. Am. Osteopath. Assoc. 2005, 105, 145.

11. Ahmed, M.; Batista, J.; Rocha, T.; Corrêa, M.; Mazzanti, C. M.; Zanin, R. F.; Morsch, A. L. B.; Morsch, V. M.; Schetinger, M. R. C. Chem.-Biol. Interact. 2006, 162, 165.

12. Zdražilová, P.; Štěpánková, Š.; Komers, K.; Ventura, K.; Čegan, A. Z. Naturforsch. 2004, $59 c, 293$.

13. Sussman, J. L.; Harel, M.; Frolow, F.; Oefner, C.; Goldman, A.; Toker, L.; Silman I. Science 1991, 25, 872 .

14. Vellom, D. C.; Radić, Z.; Li, Y.; Pickering, N. A.; Camp, S.; Taylor, P. Biochemistry 1993, $32,12$.

15. Štěpánková, Š.; Komers, K.; Komersová, A.; Masopustová, M.; Čegan, A. Z. Naturforsch. 2006, 62c, 308 .

16. Cutmore, E. A.; Guest, W. A.; Hatto, J. D. I.; Moores, C. J.; Smale, T. C.; Stachulski, A. V. J. Chem. Soc. Perkin Trans. 1, 1990, 4, 847.

17. Verrinder, D. J.; Hourigan, M. J.; Prokipcak, J. M. Can. J. Chem., 1978, 56, 2582.

18. Lock, G.; Kempter, F. H. Monatsh. Chem. 1936, 67, 24.

19. Nägele, E.; Schelhaas, M.; Kuder, N.; Waldmann, H. J. Am. Chem. Soc. 1998, 120, 6889. 